\title{
Kinetic, Equilibrium and Thermodynamic Studies of Cadmium (II) Adsorption by Modified Agricultural Wastes
}

\author{
Zeid A. Al Othman ${ }^{1, *}$, Ali Hashem ${ }^{2}$ and Mohamed A. Habila ${ }^{1}$ \\ 1 Department of Chemistry, Collage of Science, King Saud University, Riyadh 11451, Saudi Arabia \\ 2 National Research Centre, Dokki, Cairo 12622, Egypt \\ * Author to whom correspondence should be addressed; E-Mail: zaothman@ksu.edu.sa; \\ Tel.: +9665-0050-5570.
}

Received: 26 November 2011; in revised form: 2 December 2011 / Accepted: 8 December 2011 / Published: 15 December 2011

\begin{abstract}
Agricultural wastes have great potential for the removal of heavy metal ions from aqueous solution. The contamination of water by toxic heavy metals is a worldwide environmental problem. Unlike organic pollutants, the majority of which are susceptible to biological degradation, heavy metals do not degrade into harmless end products. Discharges containing cadmium, in particular, are strictly controlled because of the highly toxic nature of this element and its tendency to accumulate in the tissues of living organisms. This work aims to develop inexpensive, highly available, effective metal ion adsorbents from natural wastes as alternatives to existing commercial adsorbents. In particular, Tamrix articulata wastes were modified chemically by esterification with maleic acid to yield a carboxyl-rich adsorbent. The adsorption behavior of treated Tamrix articulata wastes toward cadmium ions in aqueous solutions in a batch system has been studied as a function of equilibration time, adsorbent dose, temperature and $\mathrm{pH}$. Results showed that the maximum adsorption capacity was $195.5 \mathrm{mg} / \mathrm{g}$ in a $\mathrm{pH} 4$ solution at $30{ }^{\circ} \mathrm{C}$ with a contact time of $120 \mathrm{~min}$, an initial concentration of $400 \mathrm{mg} / \mathrm{L}$ and an adsorbent dose of $0.3 \mathrm{~g} / \mathrm{L}$. The kinetic data were analyzed using pseudo-first-order and pseudo-second-order kinetic models. It was shown that the adsorption of cadmium could be described by a pseudo-second-order equation. The experimental data were also analyzed using the Langmuir and Freundlich models of adsorption. Thermodynamic parameters such as $\Delta \mathrm{G}^{\mathrm{o}}, \Delta \mathrm{H}^{\mathrm{o}}$ and $\Delta \mathrm{S}^{\mathrm{o}}$ have been evaluated and it has been found that the sorption process was spontaneous and exothermic in nature. From all of our data, we conclude that the treated Tamrix articulata wastes investigated in this study showed good potential for cadmium removal from aqueous solutions.
\end{abstract}


Keywords: Tamrix articulata wastes; cadmium removal; adsorption; kinetic and thermodynamic study

\section{Introduction}

Cadmium $(\mathrm{Cd})$ is a toxic heavy metal of significant environmental and occupational concern [1]. It is introduced into water from smelting, metal plating, cadmium nickel batteries, phosphate fertilizers, mining, pigments, stabilizers, alloy industries and sewage sludge [2]. Contamination of drinking-water may occur as a result of the presence of cadmium as an impurity in the zinc of galvanized pipes or cadmium-containing solders in fittings, water heaters, water coolers and taps. In Saudi Arabia, mean concentrations of 1-26 $\mu \mathrm{g} / \mathrm{L}$ were found in samples of potable water, some of which were taken from private wells or cold corroded pipes [3]. Cadmium has been classified as a human carcinogen and teratogen, impacting the lungs, kidneys, liver and reproductive organs $[1,4]$. The harmful effects of cadmium include a number of acute and chronic disorders, such as renal damage, emphysema, hypertension and testicular atrophy [2]. Hence, it is essential to remove Cd (II) from water and wastewater prior to transport to prevent cycling into the natural environment. The most important technologies employed to remove cadmium include chemical precipitation, electroflotation, ion exchange, reverse osmosis and adsorption onto activated carbon [5]. Adsorption has been developed as an efficient method for the removal of heavy metals from contaminated water and soil. A variety of adsorbents, including clays, zeolites, dried plant parts, agricultural waste biomass, biopolymers, metal oxides, microorganisms, sewage sludge, ash and activated carbon have been used for cadmium removal [6-22]. Cost is an important parameter for comparing adsorbent materials [23]. Activated carbon is considered to be a highly effective adsorbent for heavy metal removal from wastewater, but it is readily solubilized under extreme $\mathrm{pH}$ conditions [24] and is also very high cost [25]. Low-cost agricultural waste byproducts, such as sugarcane bagasse [26], rice husks [27], sawdust [28], coconut husks [29], oil palm shell [30], and neem bark [31], have been investigated to discover if they can eliminate heavy metals from wastewater. In this study, Tamrix articulata wastes were modified chemically by esterification with maleic acid under conditions that yielded a carboxyl-rich adsorbent. The treated adsorbent was used to remove cadmium (II) ions from water. The equilibria, kinetics and thermodynamics of the sorption process were examined.

\section{Results and Discussion}

\subsection{Properties of Native and Maleic Acid-Treated Tamrix articulata Wastes}

FTIR data showed bands at $3,640-3,500 \mathrm{~cm}^{-1}$, corresponding to $\mathrm{O}-\mathrm{H}$ stretching vibrations, $3,000-2,800 \mathrm{~cm}^{-1}$ which correspond to $\mathrm{C}-\mathrm{H}$ stretching vibrations, and 1,740-1,725 $\mathrm{cm}^{-1}$ which correspond to $\mathrm{COO}$ and $\mathrm{C}-\mathrm{O}$ vibrations, respectively. Further bands at $1,130-1,000 \mathrm{~cm}^{-1}$ correspond to the $\mathrm{C}-\mathrm{O}-\mathrm{C}$ and $\mathrm{O}-\mathrm{H}$ vibrations of polysaccharides. The same peaks were observed for native and maleic acid-treated Tamrix articulata wastes. The only difference observed was an increase in the intensity of the peak at $1,735 \mathrm{~cm}^{-1}$ in the case of treated Tamrix articulata wastes, which confirms the 
increase in $\mathrm{COO}$ groups due to esterification. The elemental analysis results for native and maleic acid-treated Tamrix articulata wastes revealed that native wastes are composed of $41.7 \%$ carbon, 5.3\% hydrogen, and $1.8 \%$ nitrogen, whereas maleic acid-treated Tamrix articulata wastes are composed of $45.4 \%$ carbon, $5.6 \%$ hydrogen, and $1.0 \%$ nitrogen. The increase in the carbon content is due to the increase in carboxyl content. Figure 1 shows scanning electron microscope (SEM) images that reveal the rough and microporous structure of the surfaces of native (Figure 1A) and maleic acid-treated Tamrix articulata wastes (Figure 1B). Esterification appears to have only resulted in changes in the chemistry of the surface and did not clearly change the porosity of the sample.

Figure 1. Shows scanning electron microscope (SEM) images of native waste surfaces (A) and maleic acid-treated Tamrix articulata wastes (B).
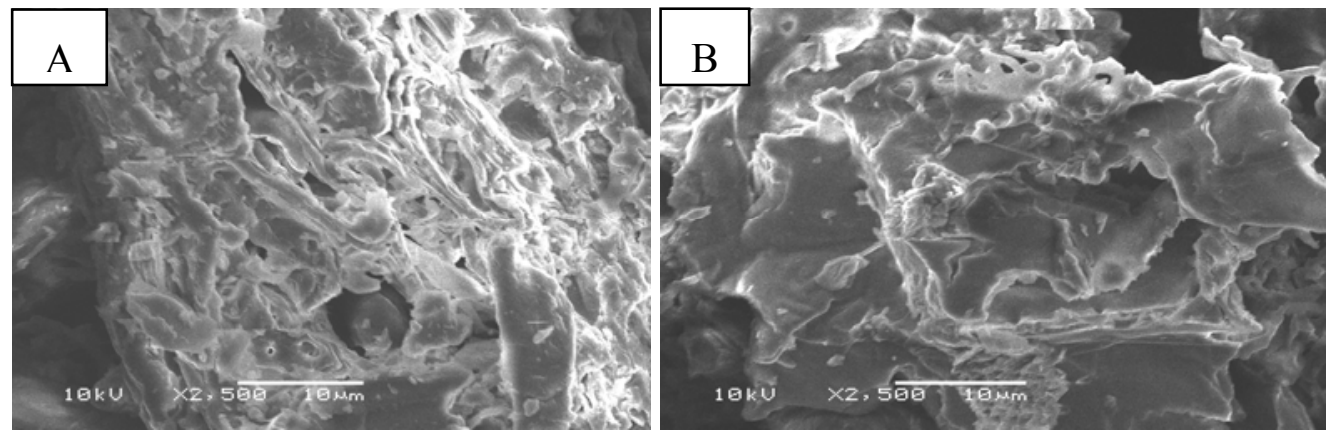

\subsection{Effect of Carboxyl Group Content of Treated Tamrix articulata Wastes on Cd (II) Adsorption}

Table 1 shows the effect of the carboxyl group content of the esterified Tamrix articulata wastes on their adsorption capacity (metal uptake per unit weight of adsorbent) for $\mathrm{Cd}$ (II) ions from aqueous solutions. Evidently, increasing the extent of esterification was accompanied by an increase in the adsorption capacity of the treated Tamrix articulata wastes. A greater extent of esterification is accompanied by formation of the cellulose maleate (Equation 1), which increases the adsorption of $\mathrm{Cd}$ (II) ions. The data show that as the concentration of maleic acid increased from 0.0005 to $0.0043 \mathrm{mmol} / \mathrm{g}$ Tamrix articulata waste, the extent of esterification increased from 131.2 to $399 \mathrm{mg}$ equiv $\mathrm{COOH} / 100 \mathrm{~g}$ sample, with a corresponding increase in the adsorption capacity from 53.3 to $195.5 \mathrm{mg} / \mathrm{g}$. These results indicate that the carboxyl groups introduced into the cellulose structure of Tamrix articulata wastes via esterification, play an important role in the Cd (II) ion adsorption process.

Table 1. Effect of esterification of Tamrix articulata wastes on Cd (II) ion adsorption at $30^{\circ} \mathrm{C}$.

\begin{tabular}{ccc}
\hline $\begin{array}{l}\text { Maleic Acid } \\
\text { (mmol/g } \text { waste) }\end{array}$ & $\begin{array}{c}\text { Esterification } \\
\text { (Carboxylic group content) } \\
\text { (mequiv/100 g Sample) }\end{array}$ & $\begin{array}{c}\text { Adsorption Capacity } \\
\text { (qe) (mg/g) }\end{array}$ \\
\hline 0.0043 & 399 & 195.5 \\
0.0022 & 315 & 137.70 \\
0.0011 & 210 & 88.84 \\
0.0005 & 131.2 & 53.3 \\
\hline
\end{tabular}




\subsection{Adsorption Studies}

\subsubsection{Effect of $\mathrm{pH}$}

As shown in Figure 2, the adsorption capacity $(\mathrm{mg} / \mathrm{g})$ of modified Tamrix articulata wastes for $\mathrm{Cd}$ (II) ions increased over the range $2.6-194.5 \mathrm{mg} / \mathrm{g}$ as $\mathrm{pH}$ values increased from 2 to 4 . Indeed, the maximum adsorption, $\mathrm{q}_{\max }$, of $\mathrm{Cd}$ (II) ions was attained at a $\mathrm{pH}$ value of 4 . This could be ascribed to the lower stability of chelates formed in highly acidic media. At lower $\mathrm{pH}$ values, the $\mathrm{H}$ ions present in the system compete with metal cations for the exchange sites on the adsorbent surface, causing partial release of these cations. Heavy metal cations are completely released under extremely acidic conditions [32].

Figure 2. Effect of $\mathrm{pH}$ on cadmium biosorption by modified Tamrix articulata wastes at $30{ }^{\circ} \mathrm{C}$.



\subsubsection{Kinetics of Adsorption}

Information on the kinetics of solute uptake is required to select optimal operating conditions for full-scale batch processing. The graph plotted in Figure 3 shows that a contact time of 120 min was sufficient to achieve equilibrium and that the adsorption did not change significantly with further increases in the contact time. Therefore, the uptake and un-adsorbed cadmium concentrations at the end of $120 \mathrm{~min}$ are given as the equilibrium values.

Figure 3. Effect of contact time on cadmium (II) biosorption by modified Tamrix articulata wastes at $\mathrm{pH} 4$ and $30^{\circ} \mathrm{C}$.

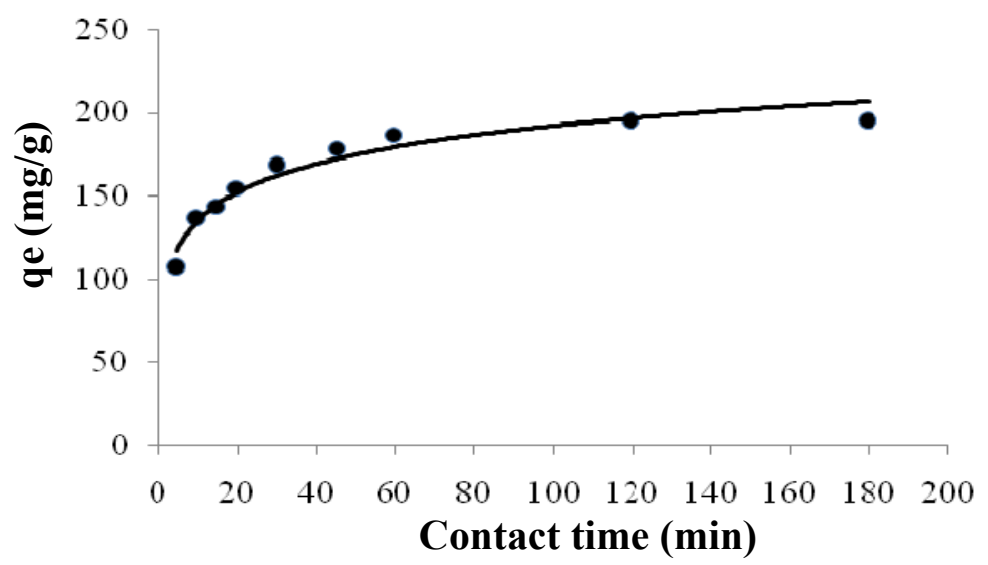


The kinetic values of adsorption were analyzed using pseudo-first-order and pseudo-second-order kinetic models. These models correlate solute uptake to predict the required reactor volume. These models are explained further below. The pseudo-first-order equation of Lagergren [33] is generally expressed as in Equation (1):

$$
d q_{t} / d t=k_{1}\left(q_{e}-q_{t}\right)
$$

where $\mathrm{q}_{\mathrm{e}}$ and $\mathrm{q}_{\mathrm{t}}$ are the sorption capacities at equilibrium and at time $\mathrm{t}$, respectively, and $\mathrm{k}_{1}$ is the rate constant of pseudo-first-order sorption $\left(\mathrm{min}^{-1}\right)$. After integration and applying boundary conditions, $\mathrm{q}_{\mathrm{t}}=0$ to $\mathrm{q}_{\mathrm{t}}=\mathrm{q}_{\mathrm{t}}$ at $\mathrm{t}=0$ to $\mathrm{t}=\mathrm{t}$, the integrated form of Equation (1) becomes:

$$
\log \left(q_{e}-q_{t}\right)=\log q_{e}-k_{1} t / 2.303
$$

The pseudo-first-order rate constant, $\mathrm{k}_{1}$, can be obtained from the slope of the graph of $\log (\mathrm{qe}-\mathrm{q})$ versus time $\mathrm{t}$ (Figure $4 \mathrm{~A}$ ). The calculated $\mathrm{k}_{1}$ values and corresponding linear regression correlation coefficient values are shown in Table 2 . The linear regression correlation coefficient value $\mathrm{R}_{1}{ }^{2}$ was 0.945 , which indicates that this model cannot be applied to predict the adsorption kinetics.

Figure 4. Pseudo-first-order (A) and pseudo-second-order (B) cadmium (II) biosorption by modified Tamrix articulata wastes.
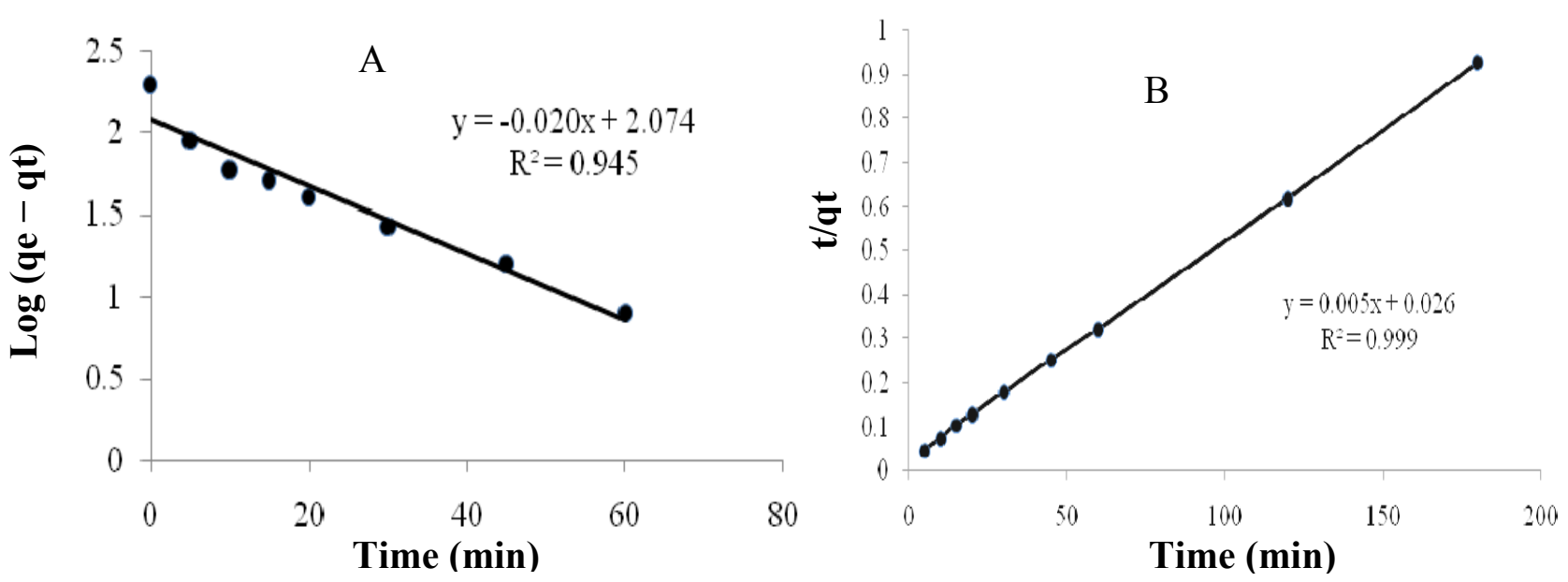

Table 2. Kinetic constants for cadmium (II) adsorption onto maleic acid-treated Tamrix

\begin{tabular}{|c|c|c|c|c|c|}
\hline \multicolumn{3}{|c|}{ The pseudo-first-order } & \multicolumn{3}{|c|}{ The pseudo-second-order } \\
\hline $\begin{array}{c}\text { Rate } \\
\text { Constant } \\
\left(K_{1}\right) \\
\end{array}$ & qe $(\mathrm{mg} / \mathrm{g})$ & $\left(\mathbf{R}_{1}^{2}\right)$ & $\begin{array}{c}\text { Rate } \\
\text { Constant } \\
\left(K_{2}\right) \\
\end{array}$ & qe $(\mathrm{mg} / \mathrm{g})$ & $\left(\mathbf{R}_{2}^{2}\right)$ \\
\hline 0.046 & 118.5 & 0.945 & 0.00096 & 200 & 0.999 \\
\hline
\end{tabular}
articulata wastes at an initial concentration of $400 \mathrm{mg} / \mathrm{L}$ at $30^{\circ} \mathrm{C}$ and $\mathrm{pH} 4$.

The pseudo-second-order chemisorption kinetic rate equation is expressed in Equation (3) [34]:

$$
d q_{t} / d t=k_{2}\left(q_{e}-q_{t}\right)^{2}
$$


where $\mathrm{q}_{\mathrm{e}}$ and $\mathrm{q}_{\mathrm{t}}$ are the sorption capacities at equilibrium and at time $\mathrm{t}$, respectively, and $\mathrm{k}_{2}$ is the rate constant of pseudo-second-order sorption $(\mathrm{g} /(\mathrm{mg} \cdot \mathrm{min}))$. After integration and applying boundary conditions, $q_{t}=0$ to $q_{t}=q_{t}$ at $t=0$ to $t=t$, the integrated form of Equation (3) becomes:

$$
t / q_{t}=1 / K q_{e}^{2}+1 / q_{e} * t
$$

where $\mathrm{t}$ is the contact time $(\mathrm{min})$, and $\mathrm{q}_{\mathrm{e}}(\mathrm{mg} / \mathrm{g})$ and $\mathrm{q}^{2}(\mathrm{mg} / \mathrm{g})$ are the amount of solute adsorbed at equilibrium. Figure 4B shows the linear relationship of the graph plot of $\mathrm{t} / \mathrm{qt}$ versus $\mathrm{t}$, from which $\mathrm{q}_{\mathrm{e}}$ and $\mathrm{k}$ can be determined from the slope and intercept, respectively. The linear regression correlation coefficient $\mathrm{R}_{2}{ }^{2}$ value (0.99) was higher than $\mathrm{R}_{1}{ }_{1}$ (Table 2). These results confirm that the adsorption data were well represented by the pseudo-second-order kinetic model, this means that the adsorption rate is proportional to the concentration of cadmium (II) squared. As shown in Figure 3, in the beginning, there is high concentration of cadmium ions so the adsorption rate is fast until reach $60 \mathrm{~min}$ then the rate become slowly until reach 120 min. Adsorption did not change significantly with further increase in the contact time after $120 \mathrm{~min}$ (equilibrium time).

\subsubsection{Effect of Adsorbent Dosage}

The amount of cadmium (II) adsorbed varied with adsorbent dosage. As shown in Figure 5, the adsorption capacity of cadmium decreased from 208.7 to $30.6 \mathrm{mg} / \mathrm{g}$ with an increase in adsorbent concentration from 0.3 to $6 \mathrm{~g} / \mathrm{L}$ for an initial cadmium concentration of $400 \mathrm{mg} / \mathrm{L}$. A similar trend was also observed for zinc removal using Azadirachta indica as the adsorbent [35].

Figure 5. Effect of adsorbent concentration on cadmium(II) biosorption by modified Tamrix articulata wastes using $400 \mathrm{mg} / \mathrm{L}$ of cadmium at $\mathrm{pH} 4$ and $30^{\circ} \mathrm{C}$.

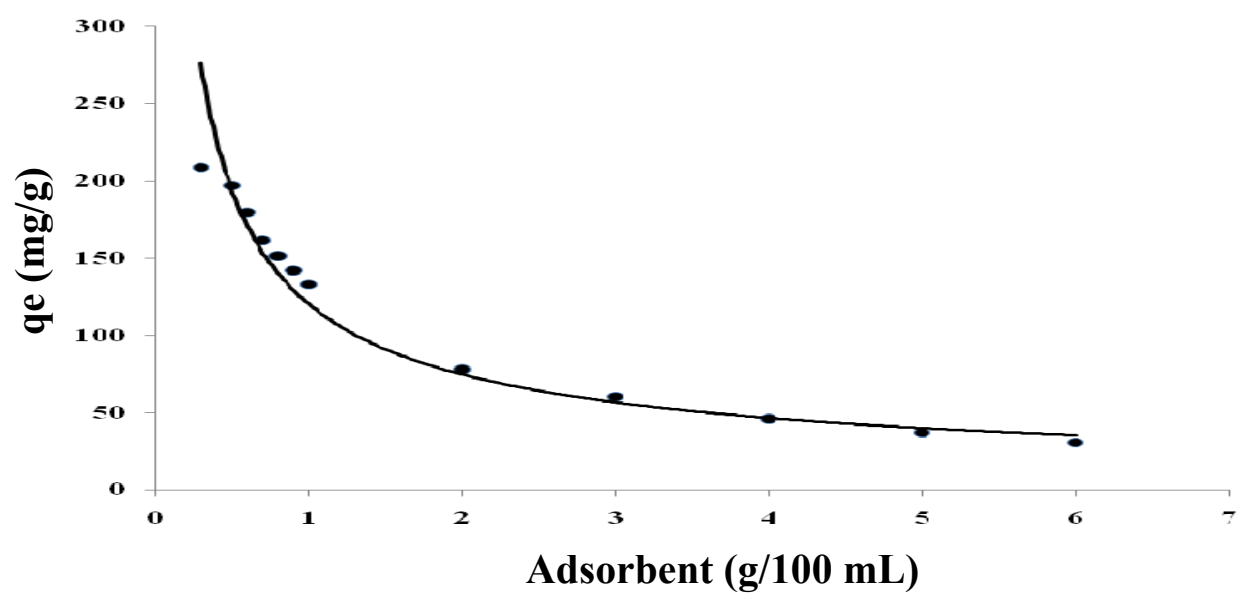

2.3.4. Adsorption Isotherms

Analysis of isotherm data by fitting different models is an important step in determining a suitable model for design purposes [36].

\subsubsection{Langmuir Isotherm}

The Langmuir equation (5) [37] was applied to the equilibrium data for adsorption of Cd (II) ions onto native and modified Tamrix articulata wastes: 


$$
\mathrm{C}_{\mathrm{e}} / \mathrm{q}_{\mathrm{e}}=1 /\left(\mathrm{q}_{\max } \cdot \mathrm{b}\right)+\mathrm{C}_{\mathrm{e}} / \mathrm{q}_{\max }
$$

where $\mathrm{C}_{\mathrm{e}}$ is the equilibrium concentration of the adsorbate $(\mathrm{mg} / \mathrm{L}), \mathrm{q}_{\mathrm{e}}$ is the amount of metal ion adsorbed $(\mathrm{mg} / \mathrm{g})$, and $\mathrm{q}_{\max }$ and $\mathrm{b}$ are Langmuir constants related to the maximum adsorption capacity $(\mathrm{mg} / \mathrm{g})$ and the adsorption energy, respectively. The Langmuir equilibrium constant, $\mathrm{K}_{\mathrm{L}}$, can be obtained from Equation (6).

$$
\mathrm{K}_{\mathrm{L}}=\mathrm{q}_{\text {max }} \cdot \mathrm{b} .
$$

The linear form of the Langmuir isotherm is shown in Figure 6. The correlation coefficients, $\mathrm{R}^{2}$, for the adsorption of $\mathrm{Cd}(\mathrm{II})$ ions onto native and maleic acid-treated Tamrix articulata wastes are 0.966 and 0.957 , respectively, indicating that the adsorption was well fit by the Langmuir isotherm.

Figure 6. Langmuir biosorption isotherms for cadmium (II) in $0.3 \mathrm{~g} / \mathrm{L}$ of biosorbent for native (A) and maleic acid-treated Tamrix articulata wastes (B).

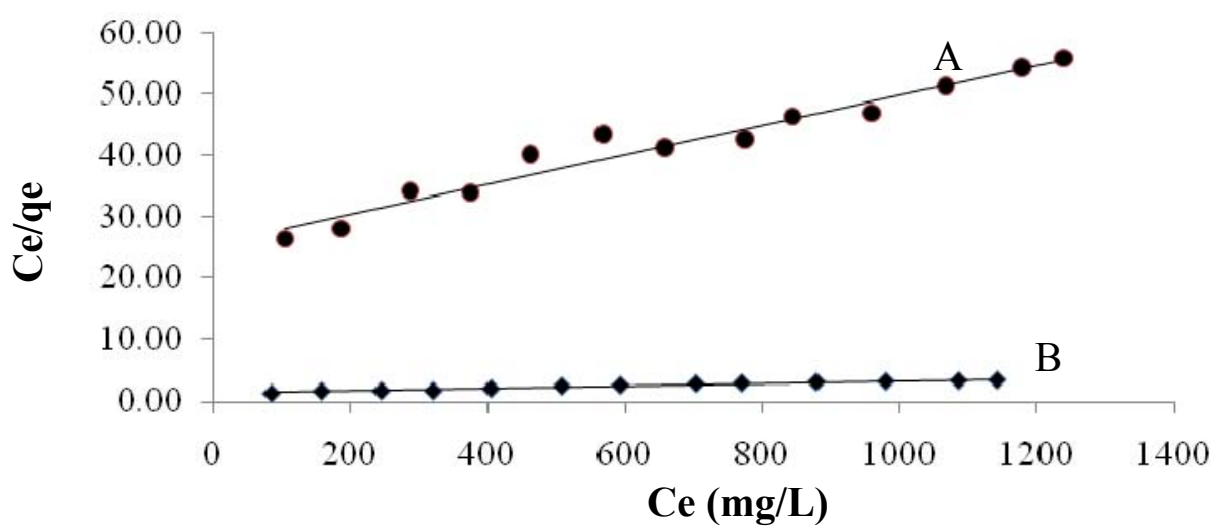

\subsubsection{Freundlich Isotherm}

The Freundlich equation is presented in equation (7):

$$
\log q_{e}=\log K+1 / n \log C e
$$

where $\mathrm{Ce}$ is the equilibrium concentration $(\mathrm{mg} / \mathrm{L})$ and qe is the amount of metal adsorbed $(\mathrm{mg} / \mathrm{g})$ at equilibrium. The quantities $K_{F}$ and $n$ are the Freundlich constants, with $K_{F}(m g / g)$ indicating the adsorbent capacity and $\mathrm{n}$ indicating the favorable nature of the process. Plots of log qe versus $\log \mathrm{Ce}$ should be linear, with the slope and intercept of the line obtained corresponding to $1 / \mathrm{n}$ and $\log K_{\mathrm{F}}$, respectively (Figure 7).

The calculated values for the Langmuir and Freundlich isotherm constants are given in Table 3. The adsorption of cadmium (II) onto native and maleic acid-treated Tamrix articulata wastes was well correlated with the both the Langmuir and Freundlich equations for the concentration range studied. This means that the adsorption of cadmium (II) onto maleic acid-treated Tamrix articulata wastes is favorable. These results are confirmed by the negative $\Delta G^{\circ}$ values (Table 4) which means the spontaneity of the adsorption process.

The linear form of the Langmuir isotherm (Figure 7) indicates that the surface of the maleic acidtreated Tamrix articulata wastes is uniform, and all the adsorption sites are equivalent. Also means that adsorbed cadmium molecules do not interact. At the maximum adsorption, only a monolayer is 
formed: molecules of adsorbate (cadmium) do not deposit on other, already adsorbed, molecules of adsorbate, only on the free surface of the adsorbent.

Figure 7. Freundlich biosorption isotherms for cadmium (II) in $0.3 \mathrm{~g} / \mathrm{L}$ of biosorbent for native (A) and maleic acid-treated Tamrix articulata wastes (B).

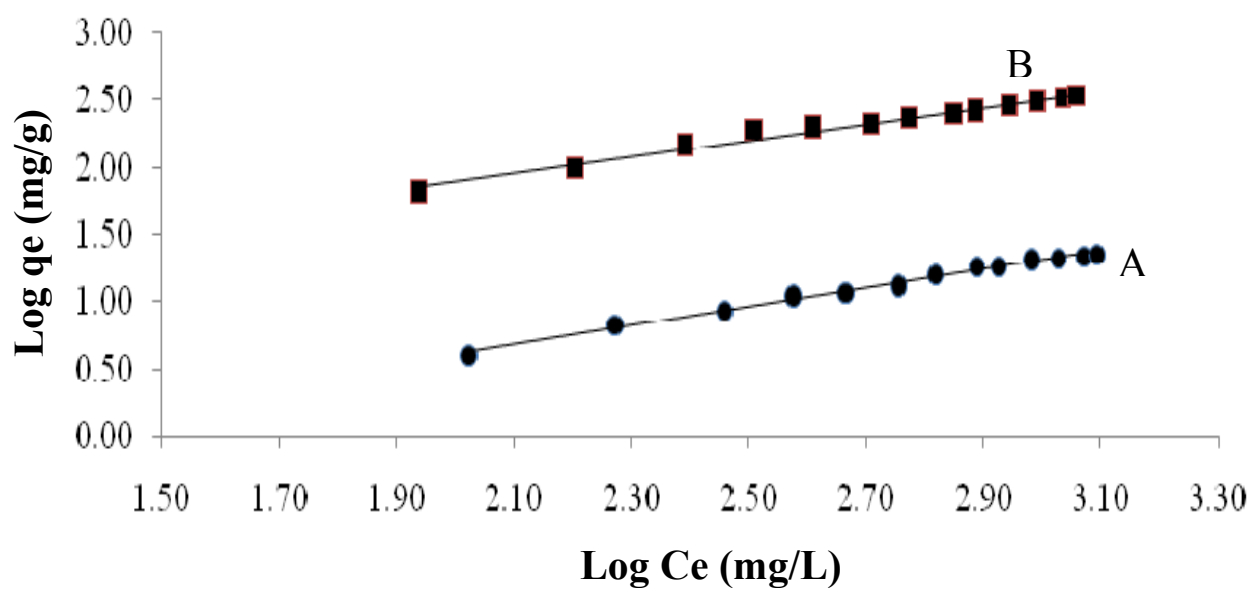

Table 3. Langmuir and Freundlich constants for the adsorption of $\mathrm{Cd}$ (II) Ions onto native and maleic acid-treated wastes at $\mathrm{pH} 4$ and $30{ }^{\circ} \mathrm{C}$.

\begin{tabular}{cccc}
\cline { 2 - 4 } & Constant & Native & Maleic acid-treated plant \\
\cline { 2 - 4 } Langmuir & $\mathrm{K}_{\mathrm{L}}$ & 0.024 & 0.8 \\
constants & $\mathrm{b}$ & 0.00057 & 0.0016 \\
& $\mathrm{Q}_{\text {max. }}$ & 41.6 & 500 \\
& $\mathrm{R}^{2}$ & 0.957 & 0.966 \\
\cline { 2 - 4 } Freundlich & $\mathrm{K}_{\mathrm{F}}$ & 0.168 & 4.93 \\
constants & $\mathrm{n}$ & 1.44 & 1.66 \\
& $\mathrm{R}^{2}$ & 0.991 & 0.973 \\
\hline
\end{tabular}

\subsubsection{Thermodynamic Studies}

Thermodynamic parameters, such as change in Gibbs free energy $\left(\Delta \mathrm{G}^{0}\right)$, enthalpy $\left(\Delta \mathrm{H}^{0}\right)$ and entropy $\left(\Delta S^{0}\right)$, were evaluated using Equations $(8,9)$ :

$$
\begin{gathered}
\log K_{d}=\Delta S^{o} / 2.303 R-\Delta H^{o} / 2.303 R T \\
\Delta G^{o}=-R T \ln K_{d}
\end{gathered}
$$

where $K_{d}$ is the equilibrium partition constant calculated as the ratio between sorption capacity (qe) and equilibrium concentration $(\mathrm{Ce}), \mathrm{R}$ is the gas constant $(8.314 \mathrm{~J} / \mathrm{mol} / \mathrm{K})$ and $\mathrm{T}$ is the temperature in Kelvin (K). From Equation (8) a plot of $\log \mathrm{K}_{\mathrm{d}} v$ s. $1 / \mathrm{T}$ (Figure 8) give $\Delta \mathrm{H}^{\mathrm{o}}$ and $\Delta \mathrm{S}^{\mathrm{o}}$, as shown in Table 4.

The negative $\Delta \mathrm{H}^{\mathrm{o}}$ value indicates the exothermic nature of the process. Moreover, the negative $\Delta \mathrm{S}^{\mathrm{o}}$ value corresponds to a decrease in the degree of freedom of the adsorbed species. The negative $\Delta \mathrm{G}^{\mathrm{o}}$ value confirmed the reaction feasibility and the spontaneity of the adsorption process. Further, the small absolute value for $\Delta G^{0}$ obtained in this study indicates that physical adsorption is the predominant mechanism in the sorption process [38]. 
Figure 8. Thermodynamic study of adsorption of $\mathrm{Cd}(\mathrm{II})$ onto maleic acid-treated Tamrix articulata wastes.

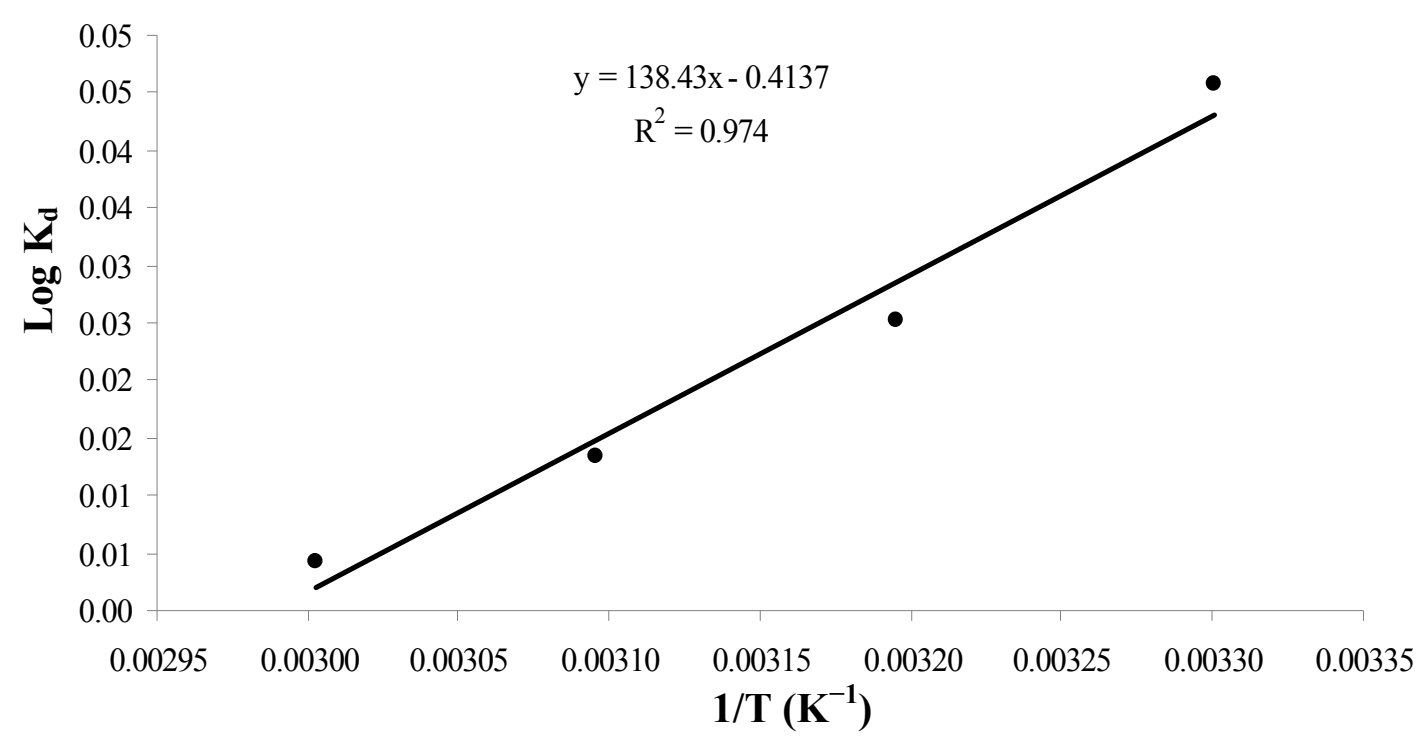

Table 4. Thermodynamic parameters for adsorption of $\mathrm{Cd}(\mathrm{II})$ onto maleic acid-treated Tamrix articulata wastes.

\begin{tabular}{ccccc}
\hline \multirow{2}{*}{ Temperature $\mathbf{T}(\mathbf{K})$} & \multicolumn{3}{c}{ Thermodynamic parameters } \\
\cline { 2 - 4 } & $\mathbf{\Delta G}^{\mathbf{0}}(\mathbf{k J} / \mathbf{m o l})$ & $\mathbf{\Delta S}^{\mathbf{0}}(\mathbf{J} / \mathbf{m o l} / \mathbf{K})$ & $\mathbf{\Delta H}^{\mathbf{0}}(\mathbf{k J} / \mathbf{m o l})$ \\
\hline 303 & -0.265 & & \\
313 & -0.151 & -7.9 & -2.6 \\
323 & -0.082 & & \\
333 & -0.027 & & \\
\hline
\end{tabular}

It is clear from Table 5 that by comparing maximum adsorption capacities (q max) of maleic acidtreated Tamrix articulata wastes and other adsorbents from literature, maleic acid-treated Tamrix articulata wastes have large capacity in the removal of $\mathrm{Cd}(\mathrm{II})$ ions from aqueous solutions. Differences of metal uptake are due to the properties of each adsorbent.

Table 5. Maximum adsorption capacities for cadmium adsorption to different adsorbents.

\begin{tabular}{lll}
\hline Adsorbent & q $\mathbf{~ m a x}(\mathbf{m g} / \mathbf{g})$ & References \\
\hline Techtona grandis L.f & 23.20 & {$[39]$} \\
Wheat bran & 15.71 & {$[40]$} \\
Corncorb & 55.2 & {$[41]$} \\
Juniper fibre & 29.54 & {$[42]$} \\
Sawdust(Cedrus deodar wood) & 73.62 & {$[43]$} \\
Spent grain & 17.3 & {$[44]$} \\
Wheat bran & 101 & {$[45]$} \\
Algae, marine, dead Biomass & 80 & {$[46]$} \\
Algae, Nile water & 37.43 & {$[47]$} \\
Tamrix articulata & 195.5 & This study \\
\hline
\end{tabular}




\section{Experimental}

\subsection{Raw Material and Chemicals}

Tamrix articulate is a moderately sized tree with feathery foliage and an erect stem usually attaining a height of 40 feet to 50 feet and girth of 5 to 6 feet. It grows faster than any other species in arid tracts. It is distributed in Saudi Arabia in Taif and Riyadh and it can be collected in large amounts each year. Tamrix articulata were collected from the Saudi Arabian desert, ground, passed through 200-400 mesh sieves and then washed with hot distilled water until the final effluent was colorless. The resulting material was then dried in an electric oven for $3 \mathrm{~h}$ at $60{ }^{\circ} \mathrm{C}$. Maleic acid, cadmium acetate, ethanol and EDTA were all laboratory-grade chemicals supplied by Aldrich (Steinheim, Germany).

\subsection{Preparation and Characterization of Adsorbent}

Tamrix articulata wastes were esterified according to the previously described method [48]. A total of $10 \mathrm{~g}$ of ground Tamrix artculata wastes was placed in a beaker, and maleic acid (0.0043, 0.0022, 0.0011 , and $0.0005 \mathrm{mmol} / \mathrm{g}$ waste dissolved in the least amount of water) was added under continuous mixing with a mechanical stirrer until a homogeneous paste was obtained. The paste was then transferred to a Pyrex Petri dish and dried for $2 \mathrm{~h}$ at $60{ }^{\circ} \mathrm{C}$ in an air-circulated oven. The dried material was treated thermally at $140{ }^{\circ} \mathrm{C}$ for $2 \mathrm{~h}$, and then cooled to room temperature and ground. Soluble by-products and unreacted acid were removed by extraction in a Soxhlet extractor for $3 \mathrm{~h}$ with water-ethanol (20:80) mixture. The final purified material was dried for $2 \mathrm{~h}$ at $60{ }^{\circ} \mathrm{C}$. For scanning electron microscopy (SEM) analysis, samples were mounted on an aluminum stub, coated with a thin layer of gold, and then examined using a JEOL microscope (JSM-6380 LA, Japan). Fourier transform infrared (FTIR) spectra of samples were recorded using a Nicolet 6700 FT-IR Spectrometer (Thermo Scientific USA). Elemental analysis of native and maleic acid-treated Tamrix articulata wastes was performed using Series II CHN analyzer (Perkin Elmer, USA).

\subsection{Carboxyl Content}

The carboxyl content of the native and modified Tamrix articulata wastes was determined according to the method reported in [49]. Previous studies [50,51] have indicated that carboxylic acids can form anhydrides (I) when subjected to heat treatment (Scheme 1). The presence of maleic acid and cellulosic material in the Tamrix articulata wastes during the heating process would allow an anhydride (I) to react with the hydroxyl groups of the cellulose in the Tamrix articulata wastes, forming a cellulose maleate adduct (II) [26].

Scheme 1. Reaction of cellulose with maleic acid.

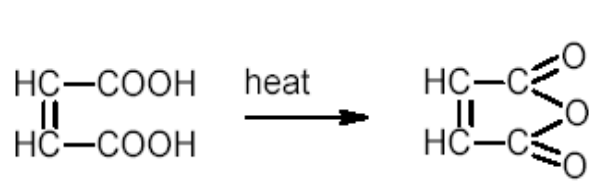

(I)

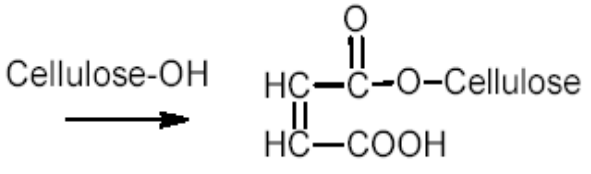

(II) 
As shown in Figure 9, the influence of the maleic acid concentration [mmol/g (Tamrix articulata wastes)] on the extent of esterification as expressed in mequiv $\mathrm{COOH} / 100 \mathrm{~g}$ sample. The extent of esterification increased significantly as the maleic acid concentration was increased, within the range studied. This enhancement in the ester group content could be interpreted in terms of the greater availability of maleic acid molecules to be converted to anhydride (I).

Figure 9. Effect of maleic acid concentration on the carboxyl group content of esterified Tamrix articulata wastes.

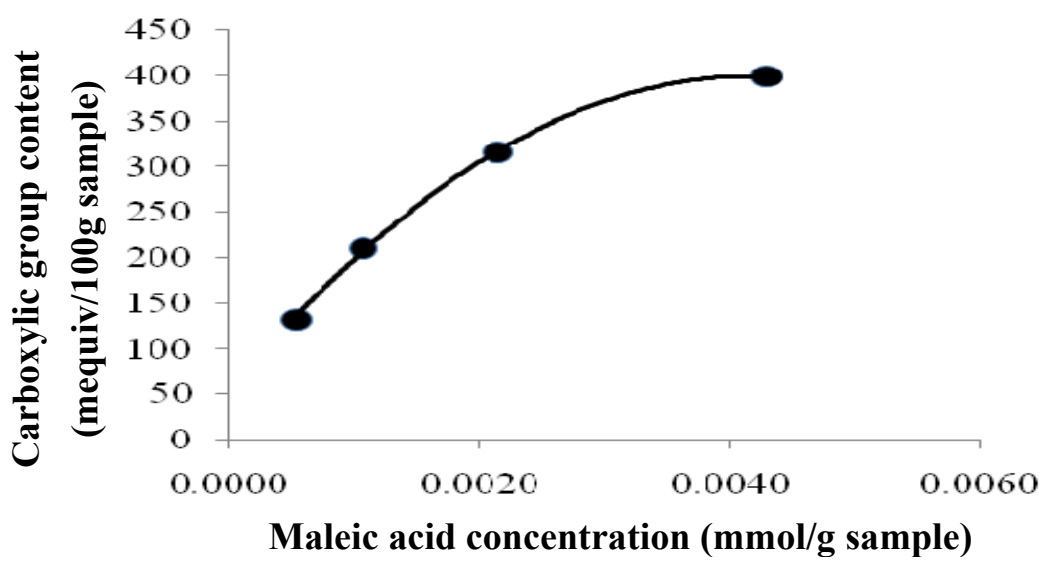

\subsection{Adsorption Studies}

Known volumes $(100 \mathrm{~mL})$ of each cadmium (II) ion solution [100-1,250 mg/L] were placed in $125-\mathrm{mL}$ Erlenmeyer flasks containing $0.03 \mathrm{~g}$ of adsorbent. The contents were shaken at $150 \mathrm{rpm}$ for $2 \mathrm{~h}$ in a thermostatic shaking water bath at $30^{\circ} \mathrm{C}$. At the end of $2 \mathrm{~h}$, the metal ion solutions were separated by filtration. Blank experiments without added adsorbents were performed at the same time. The metal ion concentrations were determined by direct detection against standard EDTA solutions before and after adsorption.

\section{Conclusions}

The maleic acid-treated Tamrix articulata wastes investigated in this study showed good potential for the removal of cadmium (II) from aqueous solutions. The maximum adsorption capacity (qe) occurred at $\mathrm{pH} 4$ and a contact time of $2 \mathrm{~h}$. The adsorption isotherms were well fit by the Langmuir and Freundlich equations. The biosorption process was best described by a pseudo-second-order equation. Thermodynamic parameters $\left(\Delta \mathrm{G}^{0}, \Delta \mathrm{H}^{0}\right.$ and $\left.\Delta \mathrm{S}^{0}\right)$ showed that the adsorption process is spontaneous and exothermic in nature. Further future work will be comparative study to test the treated Tamrix articulata wastes in adsorption of other toxic metals and also in adsorption of some organic pollutants from water.

\section{Acknowledgments}

This work was supported by NPST program by King Saud University project number 09-ENV656-02. 


\section{References and Notes}

1 Waalkes, M.P. Cadmium carcinogenesis in review. J. Inorg. Biochem. 2000, 79, 241-244.

2 Kadirvelu, K.; Namasivayam, C. Agricultural by-products as metal adsorbents: Sorption of lead (II) from aqueous solutions onto coirpith carbon. Environ. Technol. 2000, 21, 1091-1097.

3 Mustafa, H.T.; Hassan, M.A.H.; Abo-Melha, A.; Talaat, I.R. Cadmium and zinc concentrations in the potable water of the eastern provinces of Saudi Arabia. Bull. Environ. Contam. Toxicol. 1988, 40, 462-467.

4 Sharma, Y.C. Thermodynamics of removal of cadmium by adsorption on indigenous clay. Chem. Eng. J. 2008, 145, 64-68.

5 Poon, C.P.C. Removal of Cd (II) from Wastewaters. In Cadmium in the Environment, Mislin, H., Raverva, O., Eds.; Birkhauser: Basel, Switzerland, 1986; pp. 6-55.

6 Tan, G.Q.; Xiao, D. Adsorption of cadmium ion from aqueous solution by ground wheat stems. J. Hazard. Mater. 2009, 164, 1359-1363.

7 Sar1, A.; Tuzen, M. Biosorption of $\mathrm{Pb}$ (II) and $\mathrm{Cd}(\mathrm{II})$ from aqueous solution using green alga (Ulva lactuca) biomass. J. Hazard. Mater. 2008, 152, 302-308.

8 Anayurt, R.A.; Sari, A.; Tuzen, M. Equilibrium, thermodynamic and kinetic studies on biosorption of $\mathrm{Pb}$ (II) and $\mathrm{Cd}(\mathrm{II})$ from aqueous solution by macrofungus (Lactarius scrobiculatus) biomass. Chem. Eng. J. 2009, 151, 255-261.

9 Sar1, A.; Tuzen, M. Kinetic and equilibrium studies of biosorption of $\mathrm{Pb}(\mathrm{II})$ and $\mathrm{Cd}(\mathrm{II})$ from aqueous solution by macrofungus (Amanita rubescens) biomass. J. Hazard. Mater. 2009, 164, 1004-1011.

10 Sar1, A.; Tuzen, M. Removal of mercury(II) from aqueous solution using moss (Drepanocladus revolvens) biomass: Equilibrium, thermodynamic and kinetic studies. J. Hazard. Mater. 2009, 171, 500-507.

11 Tuzen, M.; Sari, A.; Mendil, D.; Soylak, M. Biosorptive removal of mercury(II) from aqueous solution using lichen (Xanthoparmelia conspersa) biomass: Kinetic and equilibrium studies. J. Hazard. Mater. 2009, 169, 263-270.

12 Benguella, B.; Benaissa, H. Cadmium removal from aqueous solutions by chitin: kinetic and equilibrium studies. Water Res. 2002, 36, 2463-2474.

13 Meng, Y.T.; Zheng, Y.M.; Zhang, L.M.; He, J.Z. Biogenic Mn oxides for effective adsorption of Cd from aquatic environment. Environ. Pollut. 2009, 157, 2577-2583.

14 Soltani, R.D.C.; Jafari, A.J.; Khorramabadi, Gh.S. Investigation of cadmium (II) ions biosorption onto pretreated dried activated sludge. Am. J. Environ. Sci. 2009, 5, 41-46.

15 An, H.K.; Park, B.Y.; Kim, D.S. Crab shell for the removal of heavy metals from aqueous solution. Water Res. 2001, 35, 3551-3556.

16 Cortes-Martinez, R.; Martinez-Miranda, V.; Solache-Rios, M.; Garcia-Sosa, I. Evaluation of natural and surfactant-modified zeolites in the removal of cadmium from aqueous solutions. Sep. Sci. Technol. 2004, 39, 2711-2730.

17 Garg, U.; Kaur, M.P.; Jawa, G.K.; Sud, D.; Garg, V.K. Removal of cadmium (II) from aqueous solutions by adsorption on agricultural waste biomass. J. Hazard. Mater. 2008, 154, 1149-1157. 
18 Semerjian, L. Equilibrium and kinetics of cadmium adsorption from aqueous solutions using untreated Pinus halepensis sawdust. J. Hazard. Mater. 2010, 173, 236-242.

19 Li, Z.Z.; Katsumi, T.; Imaizumi, S.; Tang, X.W.; Inui, T. Cd(II) adsorption on various adsorbents obtained from charred biomaterials. J. Hazard. Mater. 2010, 183, 410-420.

20 Wang, F.Y.; Wang, H.; Ma, J.W. Adsorption of cadmium (II) ions from aqueous solution by a new low-cost adsorbent-Bamboo charcoal. J. Hazard. Mater. 2010, 177, 300-306.

21 Tashauoei, H.R.; Attar, H.M.; Amin, M.M.; Kamali, M.; Nikaeen, M.; Dastjerdi, M.V. Removal of cadmium and humic acid from aqueous solutions using surface modi.ed nanozeoliteA. Int. J. Environ. Sci. Technol. 2010, 7, 497-508.

22 Visa, M.; Bogatu, C.; Duta, A. Simultaneous adsorption of dyes and heavy metals from multicomponent solutions using fly ash. Appl. Surf. Sci. 2010, 256, 5486-5491.

23 Bailey, S.E.; Olin, T.J.; Bricka, R.M.; Adrian, D. A review of potentially low cost sorbents for heavy metal. Water Res. 1999, 33, 2469-2479.

24 Huang, C.P.; Blankenship, B.W. The removal of mercury(II) from dilute aqueous Solution by activated carbon. Water Res. 1989, 18, 37-46.

25 Ho, Y.S.; Chiang, T.H.; Hsueh, Y.M. Removal of basic dye from aqueous solution using tree fern as a biosorbent. Process Biochem. 2005, 40, 119-124.

26 Chand, S.; Aggarwal, V.K.; Kumar, P. Removal of Hexavalent Chromium from the Wastewater by Adsorption. Indian J. Environ. Health 1994, 36, 151-158.

27 Srinivasan, K.; Balasubramaniam, N.; Ramakrishna, T.V. Studies on Chromium Removal by Rice Husk Carbon. Indian J. Environ. Health 1998, 30, 376-387.

28 Ajmal, M.; Rao, R.A.K.; Siddiqui, B.A. Studies on Removal and Recovery of Cr (VI) from Electroplating Wastes. Water Res. 1996, 30, 1478-1482.

29 Tan, W.T.; Ooi, S.T.; Lee, C.K. Removal of Chromium (VI) from Solution by Coconut Husk and palm Pressed Fibre. Environ. Technol. 1993, 14, 277-282.

30 Khan, N.A.; Shaaban, M.G.; Hassan, M.H.A. Removal of heavy metal using an inexpensive adsorbent. Proceedings of UM Research Seminar, University of Malaya, Kuala Lumpur, Malaysia, 11th-12th March 2003; Institute of Research Management and Consultancy (IPPP), Ed.; University of Malaya: Kuala Lumpur, Malaysia, 2003; pp. 1-5.

31 Ayub, S.; Ali, S.I.; Khan, N.A. Efficiency evaluation of neem (Azadirachta indica) bark in treatment of industrial wastewater. Environ. Pollut. Control J. 2001, 4, 34-38.

32 Gong, R.; Ding, Y.D.; Liu, H.; Chen, Q.; Liu, Z. Lead biosorption by intact and pretreated Spirulina maxima biomass. Chemosphere 2005, 58, 125-130.

33 Lagergren, S. About The Theory of So-Called Adsorption of Soluble Substances. Kungliga Svenska Ventenskapsakademiens Handlingar 1898, 24, 1-39.

34 Ho, Y.S.; McKay, E. The kinetics of sorption of basic dyes from aqueous solution by Sphagnum moss pea. Can. J. Chem. Eng. 1998, 76, 822-827.

35 Bhattacharyya, K.G.; Sharma, A. Adsorption of $\mathrm{Pb}(\mathrm{II})$ from aqueous solution by Azadirachta indica (Neem) leaf powder. J. Hazard. Mater. 2004, B113, 97-109.

36 El-Geundi, M.S. Homogeneous surface diffusion model for the adsorption of basic dyestuffs onto natural clay in batch absorbers. Adsorpt. Sci. Technol. 1991, 8, 217-225. 
37 Langmuir, I. The adsorption of gases on plane surfaces of glass, mica and platinum. J. Am. Chem. Soc. 1918, 40, 1361-1403.

38 Horsfall, M.; Spiff, A.I.; Abia, A.A. Studies on the influence of mercaptoacetic acid (MAA) modification of cassava (Manihot sculenta cranz) waste Biomass on the adsorption of $\mathrm{Cu}^{2+}$ and $\mathrm{Cd}^{2+}$ from aqueous solution. Bull. Korean Chem. Soc. 2004, 25, 969-976.

39 Rao, K.S.; Anand, S.; Venkateswarlu, P. Adsorption of cadmium (II) ions from aqueous solutions by Tectona Grandis L.F. (Teak leaves powder). BioResources 2010, 5, 438-454.

40 Nouri, L.; Ghodbane, I.; Hamdaoui, O.; Chiha, M. Batch sorption dynamics and equilibrium for removal of cadmium ions from aqueous phase using wheat bran. J. Hazard. Mater. 2007, 149, 115-125.

41 Ramos, R.L; Jacome, L.A.B.; Rodriguez, I.A. Adsorption of cadmium(II) from aqueous solution on natural and oxidized corncob. Separ. Purif. Technol. 2005, 4, 41-49.

42 Min, S.H.; Han, J.S.; Shin, E.W.; Park, J.K. Improvement of cadmium ion removal by base treatment of juniper fiber. Water Res. 2004, 38, 1289-1295.

43 Memon, S.Q.; Memon, N.; Shaw, S.W.; Khuhawar, M.Y.; Bhanger, M.I. Saw dust-A green economical sorbent for the removal of cadmium(II) ions. J. Hazard. Mater. 2007, B139, 116-121.

44 Low, K.S.; Lee, C.K.; Liew, S.C. Adsorption of cadmium and lead from aqueous solutions by spent grain. Process Biochem. 2000, 36, 59-64.

45 Ozer, A.; Pirincci, H.B. The adsorption of $\mathrm{Cd}(\mathrm{II})$ ions on sulphuric acid-treated wheat bran. J. Hazard. Mater. 2006, B137, 849-855.

46 Herrero, R.; Cordero, B.; Lodeiro, P.; Rey-Castro, C.; Sastre de Vicente, M.E. Interactions of cadmium(II) and protons with dead biomass of marine algae Fucus sp. Mar. Chem. 2006, 99, 106-116.

47 Sherif, Y.E.; Ashmawy, A.; Badr, S. Biosorption of cadmium and nickel by Nilewater algae. J. Appl. Sci. Res. 2008, 4, 391-396.

48 Wing, R.E.; Peoria, I.L. Corn fiber citrate: Preparation and ion-exchange properties. Ind. Crops Prod. 1996, 5, 301-305.

49 Daul, G.C.; Reinhardt, R.M.; Reid, J.D. The carboxymethylation of cotton. Text. Res. J. 1953, 23, 719-726.

50 Hashem, A.; Abdel-Halim, E.S.; El-Tahlawy, Kh.F.; Hebeish, A. Enhancement of the Adsorption of $\mathrm{Co}(\mathrm{II})$ and $\mathrm{Ni}(\mathrm{II})$ Ions onto Peanut Hulls through Esterification Using Citric Acid. Adsorpt. Sci. Technol. 2005, 23, 367-380.

51 Andrews, B.A.K.; Blanchard, E.J.; Einhardt, R.M. Fabric Whiteness Press Finishing with Citric Acid. Text. Chem. Color. 1993, 25, 52-54.

Sample Availability: Samples of the compounds (Tamrix articulata wastes and maleic acid-treated Tamrix articulata wastes) are available from the authors.

(C) 2011 by the authors; licensee MDPI, Basel, Switzerland. This article is an open access article distributed under the terms and conditions of the Creative Commons Attribution license (http://creativecommons.org/licenses/by/3.0/). 